\title{
Selective estrogen receptor modulator: efficacy in abnormal uterine bleeding in perimenopausal women
}

\author{
Ankita Mani ${ }^{1 *}$, Kanchan Sharma ${ }^{1}$, Arun Kumar ${ }^{2}$, R. K. Talukdar ${ }^{3}$
}

\author{
${ }^{1}$ Department of Obstetrics and Gynecology, AIIMS, Patna, Bihar, India \\ ${ }^{2}$ Department of Pathology, NMCH, Patna, Bihar, India \\ ${ }^{3}$ Department of Obstetrics and Gynecology, GMCH, Guwahati, Assam, India
}

Received: 09 February 2019

Accepted: 06 March 2019

*Correspondence:

Dr. Ankita Mani,

E-mail: maniankitaamit@gmail.com

Copyright: (C) the author(s), publisher and licensee Medip Academy. This is an open-access article distributed under the terms of the Creative Commons Attribution Non-Commercial License, which permits unrestricted non-commercial use, distribution, and reproduction in any medium, provided the original work is properly cited.

\begin{abstract}
Background: Abnormal uterine bleeding affects 50\% women of perimenopausal age group. The use of ormeloxifene (SERMS) in management of AUB is well known. The objective of the present study was aimed to see the effects of ormeloxifene on different types of endometrium.in the medical management of Abnormal Uterine Bleeding (AUB).

Methods: It was Prospective, interventional study. A total of 90 women who attended Outpatient Gynaecology Department, Guwahati with complain of AUB in perimenopausal age group (37-48) were prescribed $60 \mathrm{mg}$ ormeloxifene twice weekly for 3 months followed by once weekly for next 3 months after preliminary D and C.

Results: Ormeloxifene was found to be more effective in reducing PBAC score and ET in patients with proliferative and secretory endometrium The reduction in mean PBAC score with ormeloxifene (175.3 to 20.93)(p value 0.0001) and ET (9.6 to $2.9 \mathrm{~mm}$ ) (p value 0.0001 ) in proliferative endometrium, (179.2 to 14.8 (p value 0.0001 ) ) and ET 11.1 to $1.9 \mathrm{~mm}$ ( $\mathrm{p}$ value 0.0003 )in secretory endometrium was observed after 6 months. However, it was found not to be effective in reducing PBAC score and ET in patients with atrophic endometrium. Change in PBAC SCORE from 176.4 to 150.8 ( $\mathrm{p}$ value 0.08 ) and in ET from 2.8 to $2.1 \mathrm{~mm}$ ( $\mathrm{p}$ value 0.3 ) was observed. No major side effects were reported.
\end{abstract}

Conclusions: Ormeloxifene is effective in AUB with proliferative and secretory endometrium.

Keywords: Abnormal uterine bleeding, Dilatation and curettage, Early reproductive age, ET endometrial thickness, Ormeloxifene, Pictorial blood loss assessment chart score (PBAC), Selective estrogen receptor modulators

\section{INTRODUCTION}

Abnormal uterine bleeding may be defined as any variation from the normal menstrual cycles, and include changes in regularity and frequency of menses, in duration of flow or in amount of blood loss. ${ }^{1}$ Abnormal uterine bleeding affects 10 to 30 percent of reproductiveaged women and up to 50 percent of perimenopausal women. ${ }^{2,3}$ Factors that impact the incidence most greatly are age and reproductive status. Uterine bleeding is uncommon in prepubertal girls and menopausal women, whereas rates of abnormal bleeding increase significantly in adolescent, perimenopausal, and reproductive-age groups. Approximately 5\% of women in 30-49 age groups consult gynaecologists for AUB. Most women with menorrhagia have no pelvic pathology. ${ }^{4}$ This is the most common cause of iron deficiency anaemia in healthy fertile women. A wide range of treatment modalities are available which include medical therapy and surgical interventions. The RCOG recommends beginning with medical management before resorting to surgical interventions. Medical treatment of menorrhagia 
should aim to relieve symptoms, improve quality of life and avoid the risk of surgery.

Ormeloxifene is a non-steriodal selective estrogen receptor modulator belonging to benzopyran group. Use of ormeloxifene as a weekly contraceptive and in the treatment of menorrhagia, Dysfunctional Uterine Bleeding, mastalgia is well known. ${ }^{5}$ The drug acts by modulating the estrogen receptors on endometrium there by decidualizing the endometrium.

It is given in a dose of $60 \mathrm{mg}$ twice weekly for 3 months and weekly for next 3 months. The drug is metabolized in liver and has a half-life of 170 hours. Highest concentration of drug is seen in uterus next only to liver. Common contraindications are hepatic dysfunction, pregnancy, lactation, chronic illness, PCOS. Common side effects are nausea, vomiting and weight gain.

Endometrial hyperplasia has not been documented as an adverse effect. Centchroman, Saheli, Novex-DS, Sevista are several trade names of the drug. Ormeloxifene has been evaluated for management of AUB. Current Study is an attempt to see the effects of ormeloxifene on different types of endometrium. The aim and objective of the presents study was to determine the therapeutic efficacy of SERMS on different types of endometrium.

\section{METHODS}

Present study has been conducted from 2015-2016, on 90 patients who attended the outpatient department of Obstetrics and Gynaecology, Guwahati medical college and Hospital. within the perimenopausal age group with the complain of abnormal uterine bleeding. Study is aimed at determining the therapeutic efficacy of SERMS on abnormal uterine bleeding on different types of endometrium. Approval from the Hospital ethical committee has been taken before commencing the study.

\section{Exclusion criteria}

- Postmenopausal bleeding

- Endometrial biopsy suggestive of atypical hyperplasia or malignancy

- Cervical dysplasia

- Fibroid uterus

- Bleeding dyscrasia

- Clinical evidence of jaundice or hepatic dysfunction

- Hypersensitivity to the drug

- Uterine size >6 weeks gestational pregnant uterus.

- Women desirous of fertility.

- History of abortion within 3 month or childbirth within 1 year

- Endometrial polyp

- Adenomyosis.

Informed consent was taken from all the patients. A detailed history and clinical examination was done. As
DUB is a diagnosis of exclusion investigations were done to rule out any other possible cause for abnormal uterine bleeding. These included complete blood cell count, thyroid stimulating hormone, coagulation profile, Pap smear, pelvic ultrasound to measure endometrial thickness and rule out any pelvic pathology and endometrial sampling (D and C) was done to see the type of endometrium. Endometrial sample was sent for histopathological diagnosis in pathology lab of Gauhati Medical College.

The cases were advised to maintain a menstrual diary to record the total number of days of bleeding, number of sanitary pads used, degree of soaking of each pad, number and size of clots passed, and if dysmenorrhoea experienced.

The Pictorial Blood loss Assessment Chart (PBAC) Scoring was then done accordingly to assess menstrual blood loss. PBAC is a simple procedure for objective assessment of menstrual blood loss. A PBAC score $\geq 100$ indicates menstrual blood loss $\geq 80 \mathrm{ml}$ and is considered diagnostic for menorrhagia (Table 1). ${ }^{6}$

Table 1: PBAC scoring.

\begin{tabular}{|l|l|}
\hline PADS & Scoring \\
\hline Lightly soiled pads & 1 \\
\hline Moderately soiled pads & 5 \\
\hline Severely soiled pads & 20 \\
\hline Clots & \\
\hline Small clots & 1 \\
\hline Large clots & 5 \\
\hline Flooding & 20 \\
\hline
\end{tabular}

Patients were prescribed $60 \mathrm{mg}$ ormeloxifene twice weekly for 3 months followed by once weekly for next 3 months and were advised to come for follow up after one month. Rest of the follow up is scheduled at 3rd and 6th month. During each visit a detailed menstrual history was taken, PBAC score was calculated. Haemoglobin concentration and endometrial thickness were measured after 3 and 6 months of the treatment. Any side effects if experienced were also noted.

\section{Statistical analysis}

Statistical Analysis Data were compared using MannWhitney Utest for numerical variables and Fischer's exact test for categorical variables. A P value $<0.05$ was considered significant. Friedman's ANOVA followed by Dunn's posthoc test was used for multiple comparisons in PBAC scores, Hb level and endometrial thickness.

\section{RESULTS}

In the present study, majority of the cases 45 patients $(50 \%)$ are in the age group of 41-44 years as shown in Table 2 . 
Table 2: Clinical profile of women.

\begin{tabular}{|l|l|l|}
\hline Age in years & No. of cases & $\%$ \\
\hline $37-40$ & 18 & 20 \\
\hline $41-44$ & 47 & 50 \\
\hline $45-48$ & 27 & 30 \\
\hline
\end{tabular}

Maximum no. of patients $45(50 \%)$ were having proliferative endometrial hyperplasia.30 (33\%) were having secretory endometrium. Atrophic endometrium was seen in 15 (17\%) patients as shown in Table 3. It was observed that ormeloxifene is effective in reducing PBAC score in both proliferative endometrium from
175.3 to 51.2 ( $\mathrm{p}$ value 0.0001 ) and 20.9 ( $\mathrm{p}$ value 0.0001 ) after 3 months and 6 months respectively and secretory endometrium from 179.2 to 48.4 ( $\mathrm{p}$ value 0.0001 ) and 14.8 (p value 0.0001 ) after 3 and 6 months respectively as shown in Table 4.

Table 3: Distribution of the patients as per pretreatment endometrial histopathology.

\begin{tabular}{|l|l|l|}
\hline D and C report & Cases & $\%$ \\
\hline Proliferative endometrium & 45 & 50 \\
\hline Secretory endometrium & 30 & 33 \\
\hline Atrophic endometrium & 15 & 17 \\
\hline
\end{tabular}

Table 4: Relation between D and C findings and PBAC score.

\begin{tabular}{|c|c|c|c|c|c|c|c|}
\hline $\begin{array}{l}\text { D and C } \\
\text { endometrium }\end{array}$ & $\begin{array}{l}\text { Mean pre- } \\
\text { treatment } \\
\text { PBAC score } \\
\text { PBAC }_{0}\end{array}$ & $\begin{array}{l}\text { Mean PBAC } \\
\text { score at } 3^{\text {rd }} \\
\text { month } \\
\text { PBAC }_{3}\end{array}$ & $\begin{array}{l}\text { Mean PBAC } \\
\text { score at } 6^{\text {th }} \\
\text { month } \\
\text { PBAC }_{6}\end{array}$ & $\begin{array}{l}\text { Mean } \\
\text { difference } b / w \\
\text { PBAC }_{3-} \\
\text { PBAC }_{0}\end{array}$ & $\begin{array}{l}P \\
\text { value }\end{array}$ & $\begin{array}{l}\text { Mean } \\
\text { difference b/w } \\
\text { PBAC } 6-P B A C_{0}\end{array}$ & $\begin{array}{l}\mathbf{P} \\
\text { value }\end{array}$ \\
\hline Proliferative (45) & 175.3 & 51.2 & 20.9 & 124.1 & 0.0001 & 154.4 & 0.0001 \\
\hline Secretory (30) & 179.2 & 48.4 & 14.8 & 130.8 & 0.0001 & 164.4 & 0.0001 \\
\hline Atrophic (15) & 176.4 & 144.2 & 150.8 & 32.2 & 0.09 & 25.6 & 0.08 \\
\hline
\end{tabular}

Table 5: Relation between $\mathrm{D}$ and $\mathrm{C}$ findings and $\mathrm{Hb}$ level.

\begin{tabular}{|l|l|l|l|l|l|l|l|}
\hline $\begin{array}{l}\text { D and C } \\
\text { endometrium }\end{array}$ & $\begin{array}{l}\text { Mean pre- } \\
\text { treatment } \\
\text { Hb level }\end{array}$ & $\begin{array}{l}\text { Mean } \\
\text { Hb at } 3^{\text {rd }} \\
\text { month }\end{array}$ & $\begin{array}{l}\text { Mean Hb } \\
\text { at } \mathbf{6}^{\text {th }} \\
\text { month }\end{array}$ & $\begin{array}{l}\text { Mean difference } \\
\text { b/w Hb3-Hbo }\end{array}$ & $\begin{array}{l}\text { P } \\
\text { value }\end{array}$ & $\begin{array}{l}\text { Mean difference } \\
\text { b/w Hb6-Hbo }\end{array}$ & $\begin{array}{l}\text { P } \\
\text { value }\end{array}$ \\
\hline Proliferative (45) & 9.1 & 10.4 & 11.1 & 1.32 & 0.0001 & 2.06 & 0.0001 \\
\hline Secretory (30) & 8.9 & 10.6 & 10.9 & 1.65 & 0.0001 & 2.03 & 0.0004 \\
\hline Atrophic (15) & 7.9 & 8.3 & 6.9 & 0.42 & 0.5 & 1.08 & 0.6 \\
\hline
\end{tabular}

Table 6: Relation between D and C findings and ET.

\begin{tabular}{|c|c|c|c|c|c|c|c|}
\hline $\begin{array}{l}\text { D and C } \\
\text { endometrium }\end{array}$ & $\begin{array}{l}\text { Mean Pre - } \\
\text { treatment } \\
\text { ET }\end{array}$ & $\begin{array}{l}\text { Mean } \\
\text { ET at } 3^{\text {rd }} \\
\text { month }\end{array}$ & $\begin{array}{l}\text { Mean ET } \\
\text { at } 6^{\text {th }} \\
\text { month }\end{array}$ & $\begin{array}{l}\text { Mean difference } \\
\text { b/w ET }-\mathrm{ET}_{0}\end{array}$ & $\begin{array}{l}\mathbf{P} \\
\text { value }\end{array}$ & $\begin{array}{l}\text { Mean } \\
\text { difference b/w } \\
\text { ET6-ET0 }^{-E}\end{array}$ & P value \\
\hline Proliferative (45) & 9.6 & 4.3 & 2.9 & 5.4 & 0.0001 & 6.6 & 0.0001 \\
\hline Secretory (30) & 11.1 & 2.1 & 1.9 & 9.01 & 0.0005 & 9.14 & 0.0003 \\
\hline Atrophic (15) & 2.8 & 2.4 & 2.1 & 0.48 & 0.7 & 0.7 & 0.3 \\
\hline
\end{tabular}

However, in patients with atrophic endometrium mean PBAC score was 176.4 before treatment which reduced to 144.2 after 3 months (p value 0.09 ) but again increased to 150.8 after 6 months ( $p$ value 0.08 ) suggesting that ormeloxifene is not effective in reducing PBAC score in patients with atrophic endometrium. Change in $\mathrm{Hb}$ level in proliferative endometrium was from $9.1 \mathrm{gm} / \mathrm{dl}$ to $10.4 \mathrm{gm} / \mathrm{dl}$ ( $\mathrm{p}$ value 0.0001 ) and $11.1 \mathrm{gm} / \mathrm{dl}$ ( $\mathrm{p}$ value 0.0001 ) after 3 and 6 months respectively. In secretory endometrium $\mathrm{Hb}$ level increased from $8.9 \mathrm{gm} / \mathrm{dl}$ to 10.5 $\mathrm{gm} / \mathrm{dl}$ (p value 0.0001 ) after 3 months and to $10.9 \mathrm{gm} / \mathrm{dl}$ ( $\mathrm{p}$ value 0.0004$)$ after 6 months (Table 5). However, in atrophic endometrium $\mathrm{Hb}$ increased slightly from $7.8 \mathrm{gm} / \mathrm{dl}$ to $8.3 \mathrm{gm} / \mathrm{dl}$ (p value 0.5 ) after 3 months of treatment which again decreased to $6.8 \mathrm{gm} / \mathrm{dl}$ ( $\mathrm{p}$ value $0.6)$ after 6 months

It was seen that ormeloxifene is effective in reducing endometrial thickness in both proliferative endometrium from 9.6 to $4.2 \mathrm{~mm}$ ( $\mathrm{p}$ value 0.0001 ) and $2.9 \mathrm{~mm}$ ( $\mathrm{p}$ value 0.0001 ) after 3 months and 6 months respectively and in secretory endometrium from 11.1 to $2.1 \mathrm{~mm}$ ( $\mathrm{p}$ value 0.0005 ) and $1.9 \mathrm{~mm}$ ( $\mathrm{p}$ value 0.0003 ) after 3 and 6 months respectively as shown in table 6 and Graph 3 . However, in patients with atrophic endometrium ET was $2.8 \mathrm{~mm}$ before treatment which reduced to $2.3 \mathrm{~mm}$ after 3 months ( $\mathrm{p}$ value 0.7 ) and $2.1 \mathrm{~mm}$ after 6 months ( $\mathrm{p}$ value 0.34 ) suggesting that ormeloxifene is not effective in 
reducing ET in patients with atrophic endometrium. There were no major side effects noted.

\section{DISCUSSION}

Present Study is a prospective study to evaluate the effects of ormeloxifene on menstrual blood loss, side effects. The aim of the study is to compare the therapeutic efficacy of ormeloxifenein AUB in women of perimenopausal age group in relation to different types of endometrium. Maximum no. of patients i.e. $45(50 \%)$ were of age group 30 to 35years. Mandal et al, S Fayyaz et al, Bellad Girija et al, Grover S et al, Ravibandu and Palla et al and Agarwal and Singh et al, all have maximum no. of patients between age group 30 to $40 .^{7-12}$

Ormeloxifene competes with estradiol for binding with cytosol receptors. It not only blocks cytosol receptors but also causes their prolonged depletion and has long lasting post withdrawal effect. Thus, efficacy of the drug improves with time which is depicted by increasing reduction in menstrual blood loss with prolonged use. The results in present study with respect to efficacy of ormeloxifene in reducing MBL were comparable with majority of the other similar studies. Bellad Girija et al., Grover S et al., Ravibandu and Palla et al. and Agarwal and Singh et al. all found significant increase in $\mathrm{Hb}$ level similar to present study where significant rise in $\mathrm{Hb}$ level is seen in proliferative and secretory endometrium. ${ }^{9-12}$ However no significant rise in $\mathrm{Hb}$ level seen in atrophic endometrium.

Mandal et al and others found a significant decrease in ET with Ormeloxifene therapy. ${ }^{14}$ The findings are similar to present study where ormeloxifene caused a significant decrease in ET in proliferative and secretory endometrium. However, no significant change in ET is seen in atrophic endometrim. In the present study it was found that ormeloxifene is ineffective in reducing PBAC score in patients with atrophic endometrium $(\mathrm{ET}<5 \mathrm{~mm})$ in $100 \%$ of cases.

The finding is similar to Shravage et al in which $80 \%$ of the patients who failed to respond to ormeloxifene had ET $<5 \mathrm{~mm}$ (atrophic endometrium). ${ }^{13}$ The cut-off value of less than $5 \mathrm{~mm}$ to diagnose atrophic endometrium by TVS was taken as per criteria of Shia Salen". Though in theory, ormeloxifene is supposed to improve mean blood loss even in hypo estrogenic state by virtue of exerting a mild estrogenic effect by means of agonist action of ER-b receptors; such an effect has not been seen in the present study.

It is a small sample size and short duration study with the absence of double blinded placebo-controlled trial to control information bias. Large RCTs are needed to compare the efficacy of these drugs with other medical therapies such as progestins, tranexamic acid and levonorgestrel-releasing intrauterine system. Long-term follow-up is required to observe the efficacy of these drugs and to note the recurrence of symptomatology.

\section{CONCLUSION}

Abnormal uterine bleeding is a common problem that is encountered in the gynaecology outpatient department. The main mode of management is pharmacological therapy. Ormeloxifene is found to be effective in treating these cases as assessed by reduction in PBAC score in proliferative and secretory endometrium. But it is ineffective in treating AUB with atrophic endometrium. Apart from its efficacy, it has shown its superiority by good compliance due to convenient dose schedule and cost benefit for total therapy. Besides it does not increase the risks of breast cancer because of its anti-estrogenic action on the breast tissues. No major side effects were seen. One of the major limitations of the study was that the $13 \%$ of the patients became amenorrhoeic after onset of the treatment and not followed up later to know whether the menstrual cyclicity returned to normal or not. Thus, Ormeloxifene may be considered for the medical management of idiopathic menorrhagia, especially for patients who prefer the nonsteroidal treatment and those women who wish to preserve their fertility.

\section{ACKNOWLEDGMENTS}

Authors would like to thank Dr. Amit Kumar Assistant Professor, SGPGI, Lucknow for his technical support.

Funding: No funding sources

Conflict of interest: None declared

Ethical approval: The study was approved by the Institutional Ethics Committee

\section{REFERENCES}

1. Bhatia N. Abnormal and Excessive Uterine Bleeding. In Neeraj Bhatia editor. Jeffcoate's Principles of Gynaecology. $5^{\text {th }}$ Edition. London: Arnold Publishers; 2001. p.560

2. Fleischer AC, Kalemeris GC, Entman SS. Sonographic depiction of the endometrium during normal cycles. Ultras Med Biol. 1986;12(4):271-7.

3. Prentice A. When does heavy flow merit treatment? The Pract. 2000;244(1608):174.

4. Fraser IS. Treatment of ovulatory and anovulatory dysfunctional uterine bleeding with oral progestogen. Aus NZ J Obstet Gynaecol. 1990;30(4):353-6.

5. Kriplami A, Kulshrestha V, Agarwal N. Efficacy and safety of ormeloxifene in the management of menorrhagia: A pilo pilot study. J Obstet Gynecol Res. 2009;35(4):746-52.

6. Higham JM, O'brien PM, Shaw RW. Assessment of menstrual blood loss using a pictorial chart. BJOG: Int J Obstet Gynaecol. 1990;97(8):734-9.

7. Mandal D, Parmanik S, Surana S, Hazra A, Mandal S, Maity TK. Comparative Study of Ormeloxifene 
verses OCPs in management of DUB. International J Health Allied Sci. 2014;4(3):225-31.

8. Shahab SF, Jain S, Jain J, Jain U. Ormeloxifene: boon to perimenopausal dysfunctional uterine bleeding (DUB) women in avoiding hysterectomies. Int J Med Sci Education. 2014;1(1):21-9.

9. BelladGirija C, Lakshmi KS. Ormeloxifene in the Management of Dub. J Evid based Med Health. 2015; 2(37):6125-31.

10. Grover S, Chhabra A, Sainath B. A Study of Ormeloxifene in case of Dysfunctional uterine bleeding. Int J Med Dent Sci. 2013;1(2):162-9.

11. Ravibabu K, Palla J, Chintada GS. A study of efficacy of ormeloxifene in the pharmacological management of dysfunctional uterine bleeding. J Clin Diag Res. 2013;7(11):2534.

12. Agarwal N, Singh S, Singh S, Agarwal M, Manocha P. Comparative evaluation of the efficacy and safety of ormeloxifene and norethisterone in dysfunctional uterine bleeding. Int J Reproduct, Contracep, Obstet Gynecol. 2013; 2(2):194-8.

13. Shravage J, Mekhala D, Bellad MB Ormeloxifene vs MPA in treatment of DUB. J South Asian Fed Obstet Gynaecol. 2011;3(1):21-4

14. Hymavathi K, Gottipati MD, Prasuna SV. Ormeloxifene versus Tranexamic acid in dysfunctional uterine bleeding comparative evaluation. Int J Reproduct, Contracep, Obstet Gynecol;7(2):567.

Cite this article as: Mani A, Sharma K, Kumar A, Talukdar RK. Selective estrogen receptor modulator: efficacy in abnormal uterine bleeding in perimenopausal women. Int J Reprod Contracept Obstet Gynecol 2019;8:1495-9. 